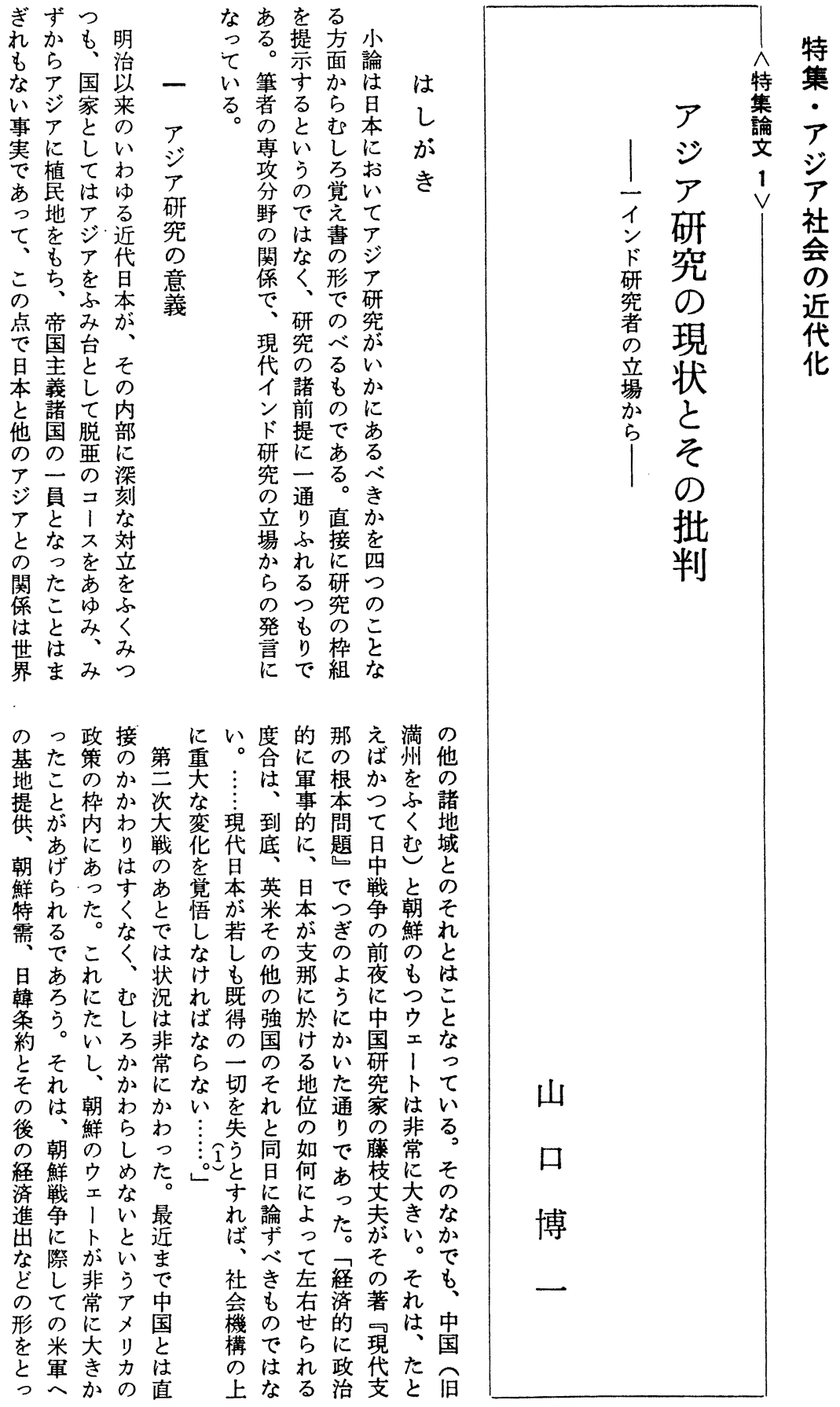


帝識対をのをむいあ自るてあかむ係をいしい見て 国、さ百直四それら立よきるえすがこ相もめすがい 主あき協ば後恶れるわううたがにば深の手のイる朝る。 義るの加に年はたれ途に。机いな諸でン場鮮 国い北がれひ等めてナし第大ンたとか国はド合人ま イは消たら○敗のくシでたな第はでになシとにた ギそ輝極こか月し努るしつ次かに兰いイとかナはた リのの化とれにた力方文支世にお次えンうつで大い福 ス頂場しとた承。が太卞那界いけ早なドてたのいし沢 と点合てな四認すな平るイ大っる英かのも。戦にて諭 のとにいら四しなさ洋っン戦てイ同っ位重さ争こは吉 対しもるん年たわれ戦日ドの旦ギ盟た㯰大らはと根の 立てみこで八がちた争本七頃本りは。はなに二なゔ をのらと旧月、、がで改億にはス朝一ど問東○るる脱 前共れを満のイ 日、は造人日この鮮九う題南年とく亜 提栄るみ州最ン本現イ法同印の領に○かとア以こ維論 と圈よと国高パは実ン案胞貿よ土お五となジ上ろ持し

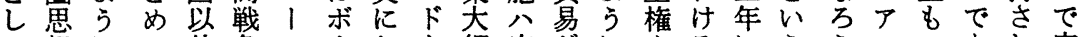
て想にて外争ル।おを綱実がにやるにううへつあれ定

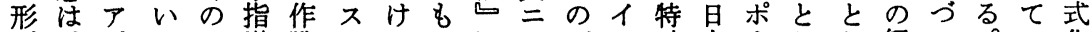
う、ジる、導戦のる、にワびン殊本、かし経い。い化

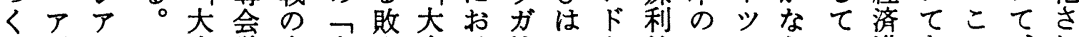
らジの東議失自退東け扶じを益フマらい進きの、れ れア盟重は敗由と爵る導めイをりてずる出てほこた るに至諸、とイと共北推、゙み、条し。がそかれよ はお意制戦サンも栄—護そリと八約も旦の、がう ずけ識争イドに圈輝林外と早本影べ中な のる、にのパ仮思しの外ににたド前本に響卜国民

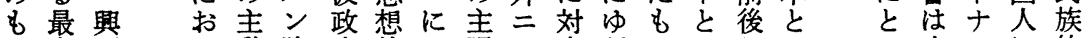

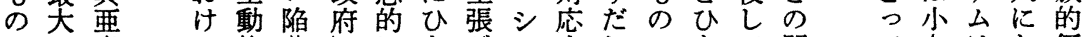
での意る権落しにきがテすねできて関てささはた偏

要る三か経いた邻っア国イに史のばっ義る中のあ なま 供で事て的ま争茂同アイド東の不こ関世亜割岡あ 与は件、浸での他じにンネ南な思に係界と愛倉っそ 先文す透よ変 の性おドシ洋か議日等秩い守天たの

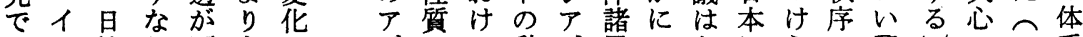
あン韓わ再むの ジのる動、民坒なにらの興活のこ系 つド条ち開身な たは約六さ近か 。楴五れかで 六キ結年るなイ 五厔のと、存・゙ 年夕よべ、在ド 以ンりトーとは 後と日ナ九な故 な本㕕五っ 禅 光対争年よ ।

ドでアの代う首 と日浮ので相 の本了华末あの 関政経、艻外 倸府済イら。交 はに外ン六日政 相よ交ド○本策 対るのネ年のな 的円重シ代厂ど に借点アのジを は款がの前ア通 うのう九半へ导

了民他向米族支かたれな亜 全族のと国即那っいる加と 域的諸ものち民たす仕にい か動植呼植フ族。る方ひっ ら向民応民ラの細多のきて 敵を地守地ン動川表いを 対亡る攵向嘉れ現れそ さら同。ィのは宍すでられ れざここリ植满はくあれら るる社れッ民州太なったは こを会らピ地、平かたア欧 と得的東ン印朝洋れ。沙米 のな経南に度鮮戦同をアに 危い済洋影支体争時た諸よ 険の的の響那台争的こ国 にで基植し、鹪前な抵よがて いるの地更うに夜抵うらと て。上はにン影に尔なたつ

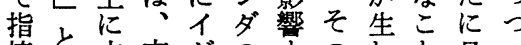

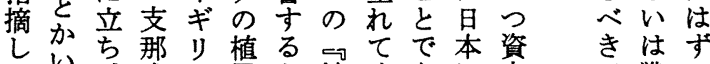
てい、或不と植くあに本每戦の

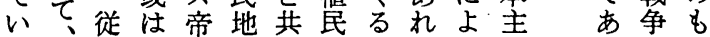


る。物いな論社夫原注手ジる会迫でう。だジンはいえく のういし会司忠意にア資科ああこ近つアド中うるな 水こがな経現雄しなを本学るっと代て全は東関かり 準と日ど済代与てる認主的いたは晒と体その係は、 がが本が論支支帝きす識義研はこ、本れのの原に未今 ど出のあ郡国たぐすの究桎と日の独運巨油な知後 れ来了る。細の主。れる形が梏、本世自命大につ数日 だるジ。細根義戦たと成開とまに界のをさくてで本 けでアこ川本势前アい紫始なたたと学左とらいあの

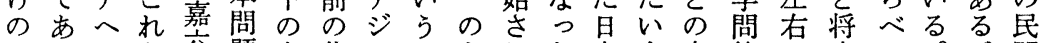
りらのら六題台代アこむれた本す交的し来て方架間 こうかに四湾了表研こうたこのる涉意かのはそ、資 え。かお管前的究ろに昭々発欧の義称不るの現本

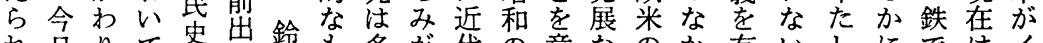
れ日りて史出鈴む多が代の意なのか有いしにではイ たそのはこ、柰のか出日は味い圧でし存か比さ主ン かれ仕著前尾兵をれて本じすし守アて在さ重えとド いぞ方者出崎基例すきにめる膨がジもでとはをしを されがた秀衛示くたつ頃の脹他アいあか心いで さの実ち近実满的なのいにでがのがるりらされわ目の か主証の藤現州にかはて羽あ他ア特。、イいゆ本程 た題的方藤現州あ机当の仁るの浯殊まン。るが度 よにに法康㐿の价然認五。アアなな゙て鉄有 りつ批や男支農るの湴郎日諳を位そ半れラ鉱利 ない判熊満那羓機と百の市本了媒置の島はッ石な

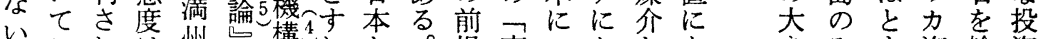

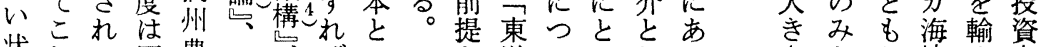
状れて同農同任の日と洋いっしうなか峡入市 況らい—業藤、関本しにててたた もらく問す場 にのるで経支枝知倸人ておののもと手ず、題ると あ書とは済那文内にのアけ社圧のいつアくでと考

れい査さ上中論とはでもな ひて機れの国争え残あし部中 とも関て論国、流念乃分国

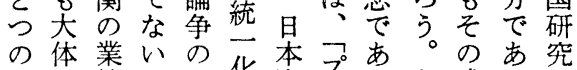
典々績しな华資 プると成っ る 型うに、か詥本帝。こ果て日 とでつ旧で論主帝とろ思、本 なあい満提争義国くが整イの た。す、ささ争義戦うさだジ 存橘同東れに、論前でれ研ア 在养様䖝たに、論のなて究研

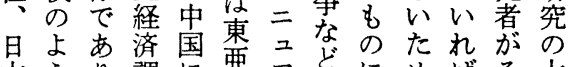
本うり、調に悪フどにめばそ大

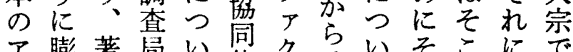
ア膨著局い体クはいそこにで

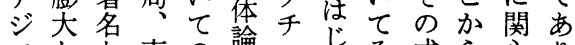
アなな東の詷之まそ成ら学り 、

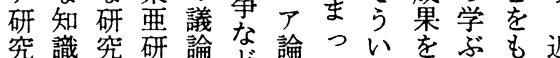
な蔵た者究整の争で方こ方帒 かしちな理連満ジのくはは本 でよ個どが連州アでみ非当思 今か人のほ経的あと常然想 後れ個主と社済生つれにで史 子あ人要ん会論産てな大あの たしになど科争様たいきる。重
にろ久をのにに

ふうののでみそ要 さし部にあての守 二わ、分するゆある しそとる。くいに なイ 位になをでただ早 にン置よすうがが単と をド老っでう、必な予 学研してあしア要るジ び究めアろ、深で比ア うはるジうまア、較は る中でア。たをと相 か国あ研そア旦の心互 ろ究うジ本こうに 朝引。法省人研に梁 鮮本こ究とこは関 研のとをっれあ連 究社が日てらりし な 会ア本社のえた ど科 ジそ会先ず歴 か 学了れ科学、更 の研自学た立を な究身的ち体 も か者のにが的つ での認理教相て 本責識解え互以 来任のして連る そで不うい関た れあ可るる的め 
れへかと支支郎そはの支て、損うら雑想のつろある゙゙ たななし認桑耕なな方郡すこ失け中誌起あてう。令出 もいりて識社尾なに向問ここでつ国をさやいる。る のうの旦し社崎かか、題しであい関みれまたここくこ でち部本ほ会泩で、む題みはるで係るるりとのうぶと あに分の加基太大列か所て例うゆのととでいよいんは

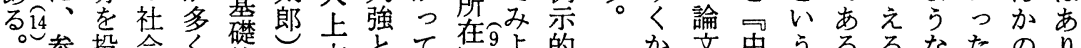

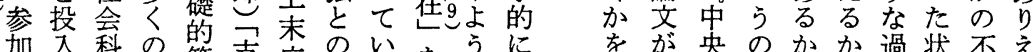
加入科の範支広のいをうに化央のかか過状不え

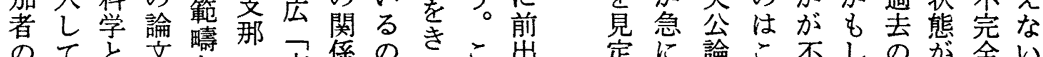
のてと文疇删支㐿のさこ出定に論こ不し公全い

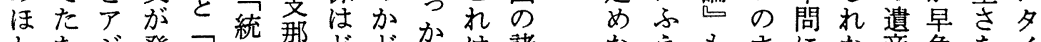

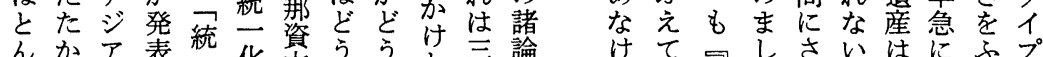

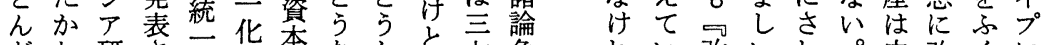
ぞわ研さ二本なかと古争机い改いれ。中改くに がさ究れ、化を義つ、年の゙る造状たし国善みつ 国れの华巡義てむ開はなか認さつい

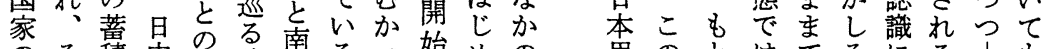
のそ積虫交諸南るつ始めの 干のの戦涉乩問京かてさに一 涉途与争涉題政ないれ矢中

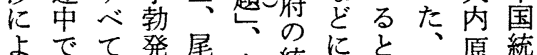
よでで発尾大統に市当原統 て あは後秀村政い杂時発华

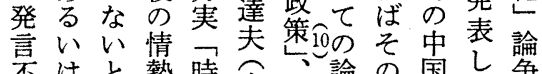
否はと勢時数し鳴論の原はた国 と年て背と愐海で動統論つ さ老景対功四、㪙一文い

想よもな時れおこ 史うにい折がいとつ最 全な昭でこどてはく近 体な和あのの全まらよ にか一ろ遺程体ずれう とか二う産度とのたや つ年。ののしぞとく てな一当部、てめい著 もに○時分まはなう作 大を月の部たまい状目 きど号総分何ちで態録 なうか合が故があでが
に性対設の提

提あて中矢前市お経範ばなたと本し っ伿策たさ起 て幣さのとれよ \&制ら性えたう 大改に格ば問な 以革右、南題簡 に、の民京は単 参農要族政実な 照村約的 府に要 し協に統 の多約 う同は一性岐か る組あに格にら も合げお、わも の等なけ外た理 で々かる資っ解 あのついのたし り問たわ役のう 題がば割でる 両の工上市よ 国 解業か農るう 研明のら業がに 究は発の政

者現展道策そこ の代段とそれの あイ階下のら論 いン多他の争 だド労らの多の のの働の経くな 共研力道済のか 同究のの建もで

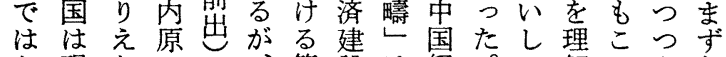
な現なのす、第設は経。て解のあ矢 く実いいも藤焉も相済そ三し資り、内 大にがうそ枝のこ互はのつ経本、原 衆は、よ流萻のに半ひの済主そは を早大う流著場上連封々立的義の 原本上に書をう関建つ場資化に中 動にの坦を盖代なし的はか本にな国 力た 説々く前表性あ矿ら的積いは といもとん出梦格っ半上のに極手資 しす矮しでるをて植の反中的は本 てる内たいもの強お民前論国にほ主 統民原資るこは化り地揭がを貢か義 一族説本。の鳴专、的論な援献な化 の的と主こ立海るしで文さ助しらし 方な共義の場海だかあがれ专てぬな 向抵通化立に大けをり代、心い南が に抗性の場近村で世、表論きる京ら 向をを方のく、界こ守争ここ政民 5 通む向見尾尾る恐れるはと亡府族 でじつを解尾崎と慌らも注を公的 あ、公とに崎のみもののぼ主日あ国 ろ南式るよの前て南三で三張本る家 う京論とれ睍出い京重、うしはこ的 と政でいば代論る政のそ巴たこと統 い府あう、支文。府吕れの的

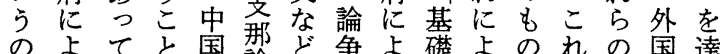

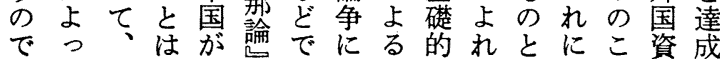


あ内内少らなをなと満く地一あうの事のあに研 るこでぞながるるすすなか鉄が的定りに週実研げお曌究 そ分批らが行重はのてを所鉄い視こ題誌橘の論て州必 の野判れ、さ新なでか多属関う角の、菜棈系じはの要 全で的よこれ書いあらく者係規にうっっの譜てこ研を 容の言うのてと。うのので者定たち満満雑をみれ究示 は研論へシいいまたい書あでをつ前州鉄誌ごたはは唆 ま究は四りるうたがく物りああて言経調でくい独もし だに封三!。シ四、つや、うた满者済查あお自とて 筆お殺年ズこリ二こか論、たえ州は年月うおこのよい 者いさ九なれ、年れの文大が経か報報たま机研りる。

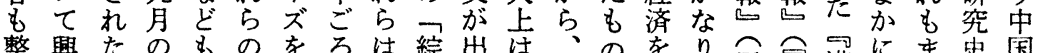
整興たのものをろは綜出は、のをり气河にま史国 理味 。马満テ刊かか合さそ結で分雑亥満洲のた在研 しあ満鉄 1 行らな調れの昫あ析多年蒙評べ整を究 てる鉄関マし中ら租た二右るしな年事評る理っの

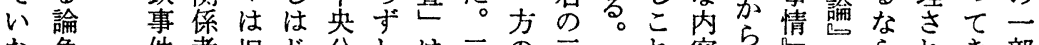

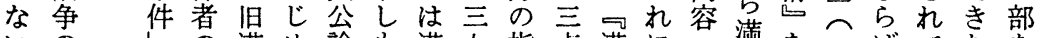
いの年満め論を満九指点満に萭をこばてたを がひそ執州、社旧鉄年導壱州つあ鉄兰九、心のな 、雀にすで満のに的通評いるるた 三三主なです こっ他活関くは州調い論し論てがよ年三要いあも こがに動籿な霂の查わ各て半がっ九年な分るの で満よのるく鉄み活ゆで発も封叮て月八発野かで も州つ最もと弘に動るあ言そ建年刊号月表でらあ 大経て後のも報かの大つ者の的報行か二手あ別る

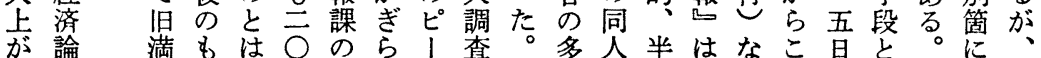
二争州の加冊編れク部こくの植ほどの創し戦と日 方で国にぎ以にたを制のは多民ぼがよ刊て前り本

ず注かのしはと外にた及論う。中出とこぎ連さ南主西の しさ加ういれ州自1ずで日国う比の性るに型ると事 されれなるはをや由ス教本研る較ほ質もは問の者 をるら植の血昌吃に正其に究の加の淽北題見で 暗。は民にを本日な一に支よとで日满点解あ 示北自地たもが本っ応西那るなあ本旧のふの型はのっ しの立といっ領改たの洋朝朝らるに満でく経、、対て て著のちして有造と完人鮮鮮ん。州あみ済農モ立 い作能が、口す法い成がにのでるにる、的民人な大

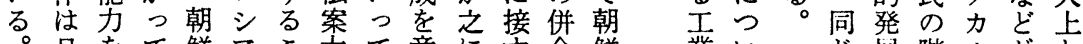
日をて鮮アこ光て意に导鮮業い展階ルがと

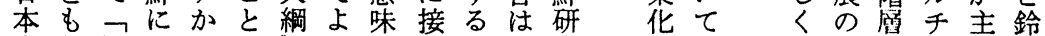
人た同つらを心旗度分二軸木

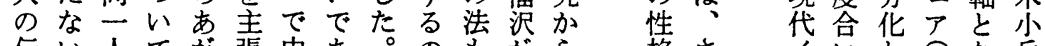

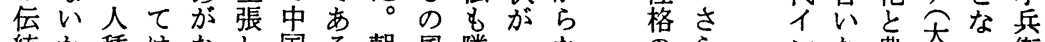

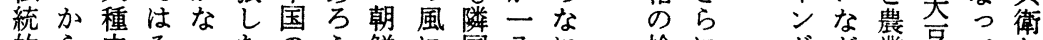

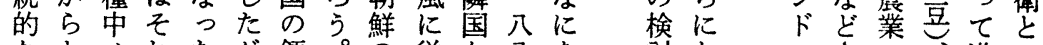

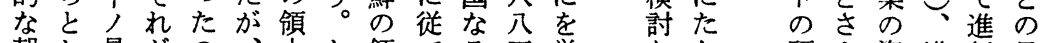
朝し最がの! 圭か領てる五学なと研資満行見 鮮て壬イでこ弆つ有処がつぶどえ 究ざ本鉄し解 観合近ギあの保てに分故明が蓜に主のたの を理キリる場全北よ打治とい満おな義独と差

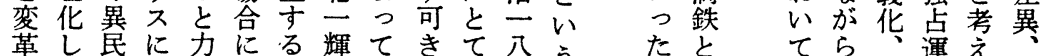

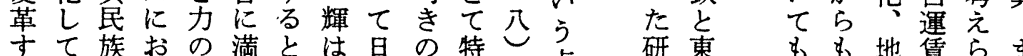

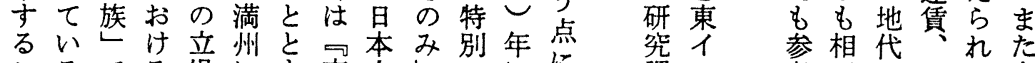
こるでる場にも支人州方にに課ン考亘のいる大

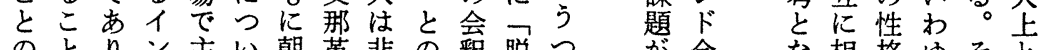

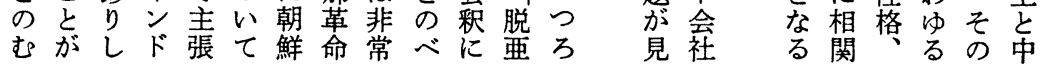


るジはた究いびい学中つ思研日たと武しとて職あ

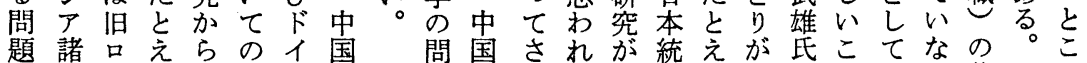

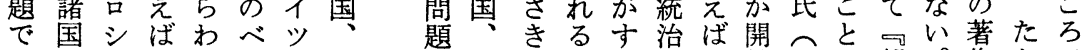
あでアそれる研朝を朝の。すや朝始二で朝。作とで ろむでこわ能究鮮さ鮮北をむそ鮮さ九あ鮮今にえこ

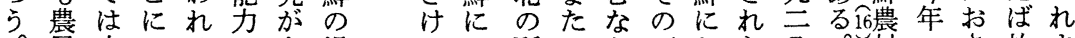

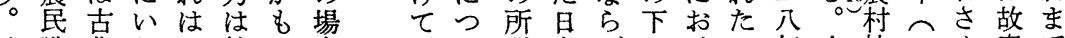
イ戦典わい筆つ合通い説本ばでけの年小社一め森で ン争的ゆろ者意にるてを統イのるもか論会九ら谷の ドとなるいに義つわの批治ン工凟ひら執の七れ克朝 もか形西乃はにゔけ研判とド業本と敗筆研三て巳鮮 そらで欧ななつい究すイ研化主つ戦中究年いへ研 のみ展派示いいて はをるギ究の義のまに皇しる二究 例 合開と唆のて 外つさスをだもイ でたれラうが若ン はりてヴけ、年ド なしいオるとふ研 くなるフこく机究 ヒら、ルが旧おた ンく多の出口きい ドりか問来シたし ウ返机題る lさすがとに。旧 教れくあ思つこ品 とてなるわいれシ イ出か。れてら号

スてれこるのにお ラいアれ。研つよ

ゆ考こリに性の機でたがに朝九の 加え不格萠緣同ま出な鮮三整 かるが統っと芽でじた版っ論占七理 なと出治ていなくまさてに年は

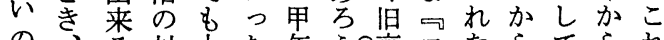
の、る対大た午う领エたらてられ だいで比いよ農。城コの鈴も敗ま がわあをにう瓜わ帝ノは李を戦た 、ゆろ方学な戦れ大ミこ栄とまお 小るうるぶ諸争わ在スの态をでく 論ア。なと問へれ職卜意郎っ旧れ でカ らこ題一にしに味著た京て はデばろに八とか誌で作検城い 割ミそがつ九うら上よ集討帝る 愛ズ柿い四てのでろのは大よ し台にるて年は、鈴こ冊さに方

時るパのやもにばい। 期とテ内統普はれてルそないジ本イの然、にの問て教 とい1容合通ってで・れいにアのツで成口つお題共と 独うルがにぞいあパはがち諸すには行シいそが同の 立意が十よのりるるテイイが国ぐまなきアてらあ体共 後味イ分る意と。。|ンンいのれでくでのはくるの存 のでン吟イ味ビこかルドドな研たたてあ場他は。問な 時こド味ンすスれれこのに究社どもろ合に意こ題い 期ののさドるマはは二独関。に会り後うかも識のがし とよ近れ統所ル興イ八立しこお科つ進。らささ改あ対 をう代て二はク味ン後たこい学少性そさまれ革り立 うに国いの単にあだ五ネ問でて者ざとれらざざは、の なよ家る達にたるで।ル題はもたるいはにある第さた

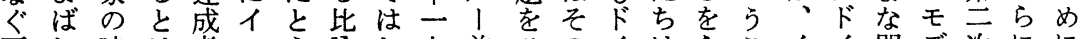
要れ建は者ンえ喻し九首ひのイはえこイイ問デ次にに のる設いとドらでば五相と例ツドなとギツ題ル大第複 よに者えいのれあし○のつとのイいにリのがと戦一雑 う值となう鉄たつばしものと近ツとつ場考な後资な なししいに人場てつととべて代やいいや合考っの革形 存、て。と、合アイいでて史口うてフにたたア命を 在かもこどあはジンう副みあかシこ世ラまらを浽と でれつれまるまアド政首たまらアと界ンでれのアのつ あのとにっい机のの治相いり示にで的ス寸ると諸スて る事もたてにで政ビ家を。適唆注あにのすが思国トい こ業重いい旧あ治スのつ と架要して王ろ家、位と を民な、侯うでル置め 主族人筆こ領。こクゔた 張運物者ののけのしけサ

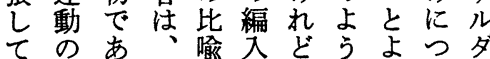
切者貝考歴む、わにルる でうし。え史のそれおイ。 なけてこたをはれるけピこ いるきの場理いは。るンれ かこた点合想わさ旧土のに もとがかに华ばて口地改関 しが、らは守自お改鞕 
文年的 521之と志日他どのや的

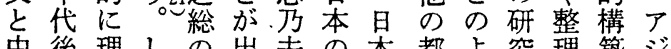
中後理しの出夫の本都上究理築シ 国半解か問来了位の合うにだはア三 革以すし題る近置歴でなつけと研 命後る、提。代亏史や手いでう究 凹に记を東け学やがてもての おつめ白のた游不か批たい現 よいにの意前ジ関お十り判いま状 びてはア味節ア守い分を的へだか コみこジにににるてなあにんのら 辛なれアつふお一注た検なぞす 亥け台をいれけ連羽択え討仕むれ

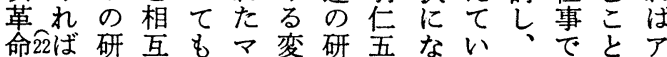

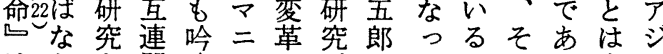

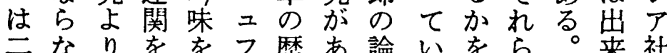

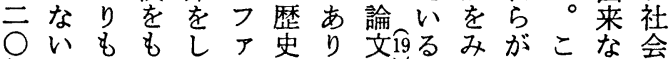
年で対っなク的、以。てアこい論 代あ象ひけチ諸最来 なる時とれュ形近近 が。期つばア態20の代 ば。をのな論岕もの で野さ全な争なのア

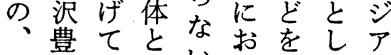
日量乙乞い市てに 中の九てでるげはお 両可歴古服る大け 国孫○史ろ部こ江る
みジで。文 たアはこ車の だ研つのき し究ず蓄も 紙にい積の 数たてのの そ心従発体 のし来掘采 社前れい検 。会節变う険
るか分動自物い つの用がる

たら揮権そイ

めさ者運らン

にをで動くド

そむあのこに

れつつ抑のお

だてた压パい

けいの者テて

問たがと、日

題と重しル本

がい要てでの

圧うなたあ大

縮の相ち万久

さで違はう保

れは点だ。利

てなでかた通

生くあっだや

し、るたし伊

たイ。の大藤

とンまに久博

いドたた保文

うのいた

乙独パしち原

亡立テ他が敬

と達 1方はに

な成ルはじあ

のがが民めた

でお三族かる

あそ人運ら人
は開術中時支太武れ日アほおいふ国 中心的国の那郎つ直な本湆とうでくにつ 国し記研研の氏ゔないにアんんと農んつぎ のた述究究経にいど。関研どす村でいに 歴もを史水済ふてのな究最る共いて今 史の主上隻とれ戦諸おるに後も同ての堀 にと要でに社た前氏、有おのの体貴も誠 つ内比会いには中賀い社でと重の二 いて容ジし去。ア今国喜て会あ都でで氏 ていとヤてを氏堀に左こ調る。市ああの

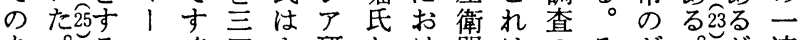
あ。るルぐ四ま研とけ門はのそギの゙が連 まし諸のれ年ず究対る氏た結れル氏、の りか著著たにウに立共のと果はドの他都

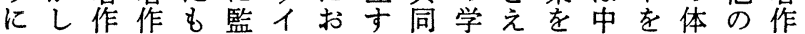
も本へとの訳ッいる体問ばを国基系アに 停書のなで者トて見のとアとに軸はジふ 滞の批らあとフ多解存共プにおと根了れ 的詳判んりしオくを在通口しいし岸にて な細ので、て、のとを性、ててて佶たお 見な上そか出ゲ著っ否をチ展日中絊古 解分にれつ版ル訳て定むは開本国仁すた で析精まてしの者いするまする 井るい あの繖で大てっをたるる学史田関 うおな解の点のたて者的塆心こ たもるて本る24体こででくいが解両をれ むる地広過し 旗あこるお明氏そら

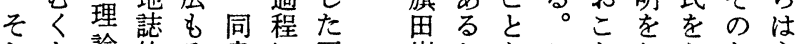
しと論的そ書に平 てこを・れはあ野 氏ろ展技が当る義
巍かな日なおうな主 \&る本つこけかに 福しがのたなつに中
わを $11 \bigcirc$ 中を れ全ア年国ふ 体!代にく とウ末おめ しイかけた てンらる東 歴協三国ア 史定 $\bigcirc$ 尼 的气年革了 に三代命の 考二はと歴 え年じそ史 て三めの と ゆ月に挫\& くい折な 際のたのつ の意る問て

出味人題以 発点考ド共。 之えのに筆 なる反こ者 るこ英れの のと運に立 でが動す場 は現とぐか な代ガつら いのンうす かアデいれ

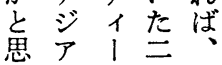


ワ他傾り平はたこいめ本われのみ題とす諸こ兯年に

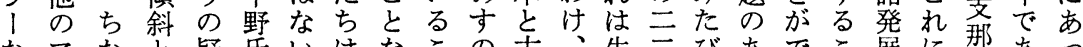
なアなと疑氏いはなこの古、生三びあでこ展に郬あっ

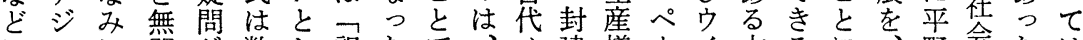
にアに婯加数し訳たで、メ建様!イ方るに䧉会たは みと、係の冊て編歴あ右キ的式ジッ法。よ個氏科こ本 らはウでこのい者史るのシ社ににト論とり、別が科々書 れこイはるアるの像。東コ会よあフ的を市的よ学がの

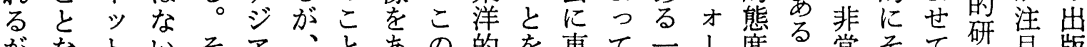
がなトいそア、と市的を東て二小度る常そて研目版 、るフでの研そばた理社い洋東枚ゲではにれい热さが

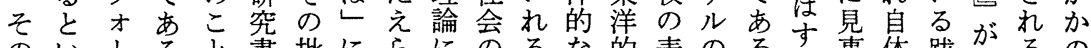
のい1らと書批にらに市るな的表のろす事体跋宇る。 源うゲうは学判おれよ発のそ社は可うなにとの佐。ロ 流説ル。氏公点い、っ生でれ会原東。な各しな美つ日

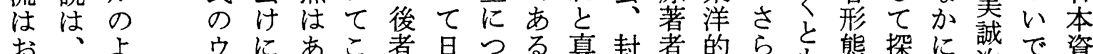
そ現う

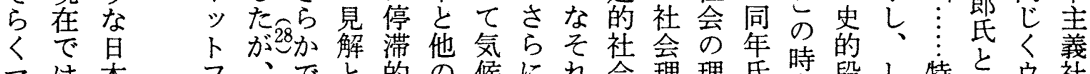
マは本 フ、でと的の候にれ会理理氏期段し特とウ社 ッ梅がオこなかとア的かと論論は期階か定共イ会 ク棹ヨ1れいなみジ要れを古をし森たにるの共ッの ス忠 1 ゲら。らなア因の区代集を谷お類の社でト譏

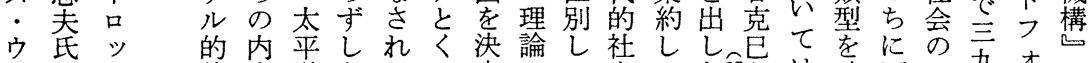

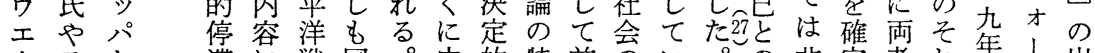

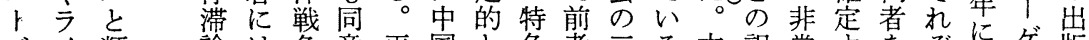
バイ類論は争意平国と色者三る本訳常守索ぞにゲ版

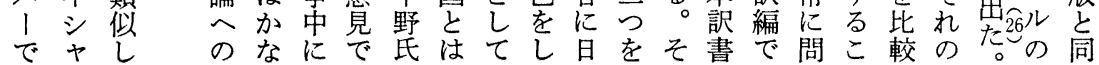

りこ久動ろ橘ジ記い的かなエッ批社五しれれ䄪か あ

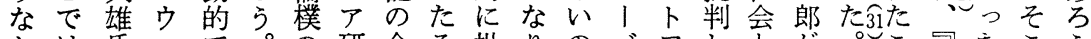
かは氏エで。の研今る批りのバフしとが吃したこう ろそに、あ橘そ究堀足判否で、オて西批ウと市かでか うの代バるのれの氏場す定はの!い欧判エが劣れウ とア表 ! かえ|評のはるさなアゲる思的! あののエ

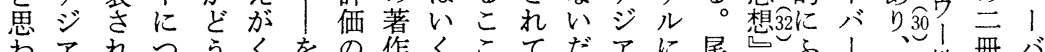

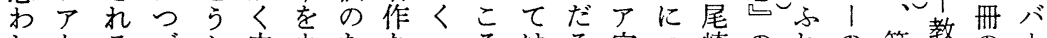
れなるつかか中ウたなつろはろ宗つ崎のれの第教の、 るど比い。国エめどかみいう䒚い秀第て独空仏書を 故へ較て 民にににすはるか論て実四いジ章佁物す 赤の経そ衆バはそで今の。に興も章るアは教のこ 羽適済の の 少れに後で管た味獄㩆宗まのうし 裕用史影像のくをきのあ見い市中東、教だ第ちだ 氏の学響注に見すこるでするか洋島論邦第与け の仕とをは教こ出かとがはる見らに恭、訳二章需登 方アった論れ标机、か立解の拉彦とが章教場

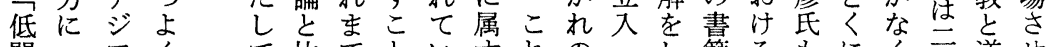
開つアくて比でとい机のっし簡るもにく 発いと ウ ウ較のがるるを学ための資戦中、年教た 国てのけエし道出のの矛説批しな本争国第年心い。

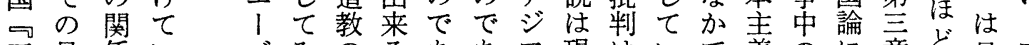
エ見係いバみのるああア現はいで義のに章ど最

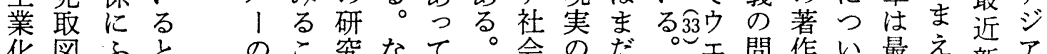

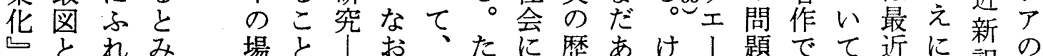
のみたら合が|化ただ即史られバ起あは邦一訳宗

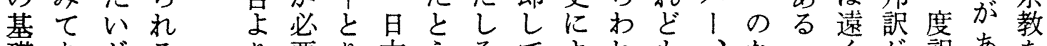

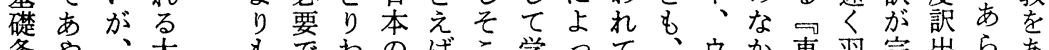
条や、大古でわの价学って、ウか東羽完出らあ 件まこ㙇能あけア前に問ていウイで洋仁成さわつ 


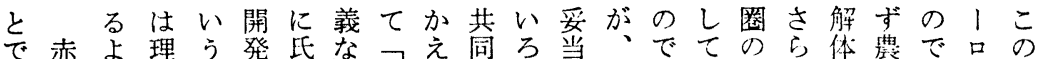

は羽う論想国はの反る体いな上あこ発に、業あッ論歴

あ説に的定の西で帝ともるものるの废、人生るパ文史

るに思にに工ヨあ反心变問の所。三とこ間産。やは的

がつわは立業 1 万封う革題で説氏つにれ類力そア副経

実いれ封つ华口う建のしがあはののよに型のれメ題験

際てる建てがッか方は、あるイ主課つ加の增にリのと

にみ。制いかパ、の今モろらンた題てえ変大よ力しの

はた度るつをそ中旦ノう。ドるをつて革がれ経め対

よっなのて規机身で力。しな関お内モな要ば済す比

りいいでの範とではルたかど心こ部, ゙或史よに

広でしは西化もあどチとしの地な自力をさ前研うお

いに前な欧し別る $う$ ここ現域う給ルと机近究にい

意近いとて個といアばの状はた型チをる代の今て

味こ代で同いのしううの政線批ブめ産ュなが的意白

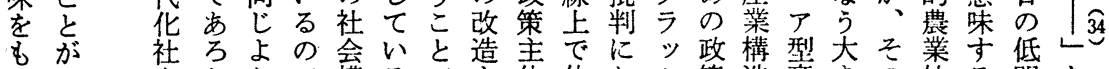

うら会ううで構るでも体体おう策造産きの社る開を

もは劣なな成。あなと采い・主業なた会と発検

のひ批。資ななしろしい化てア体の構社めのこ国討

とと判い本いのからとうをもフが建造全に工ろの寸

しまのい主ででしかげがす示り必設の变は業を研る

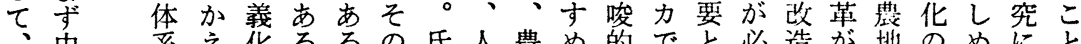

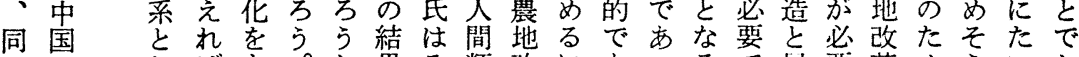

じにしばも。か果そ類改にあっるで局要革めういか

く関て氏たし。は机型革つり、た、地で、にとしえ

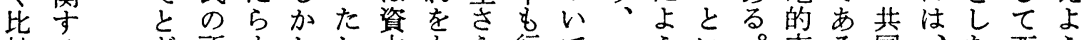

較るど所すし・し本も交行て二う心。市る同、た西う

経こま説と低か主っもいは応だうそ場。体まも寻

内系がさ民は本る本歴

商に、れの帝主が主史イ

業つ主た富国義、義をン

にいとを息国む国たド

おてしのは義たしイどは

计してでイ時るろギっ中

るの.重あギ代こイリて国

東第商るりよとギスきと

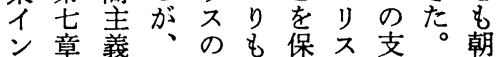

ドフの自べ以証は配ご鮮

会植批闫前さそをくと

社民判主ガのれの簡む

の地に義ルこたイ世単

独にあの領とと炎笋にな

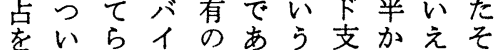

批てれブ約っべ配らばの

判レてル㕕たに主、他点

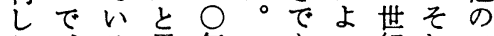

な、る思年アあっ紀れア

がイ第わ後ダろてにはジ

らン四れの厶うもかむ了

もド編てて・。つけつ諸

けのコい七スそとてと国

つ貿経乃七ミの主うむと

し易済る六スイ先け先\&

てお学こ年のン進た進ち

$1 よ の の に \neg ト ゙$ 的の的が

ンび諸書出諸領なでなっ

ド国体物版国有資あ資た
なパし機るつは中著国済 るとてを中のこ国経史 と接寻国類の農中済学

四指触 1 有農型論村国史の 摘于口し村主工経専立 しるッて正対の業済攻場 てにパい業比末の史のに

ドいさをなはし尾考研田た

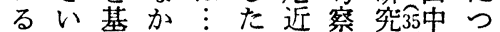

のし準っ

はてとた之ちで元の俊搉

うのすレれ、中四第氏定

な中ると自近国年言の生

す国外結身帒の執部批氏

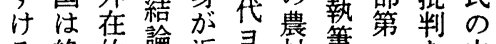

る絶的論近寻村笔第文中

と対なし代 I禁に章と国

こ的批て化口業に早り経

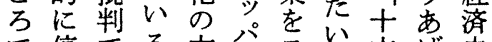

で停でる。方資寻六壮史

あ滞あ。向資门する。研

るし 可界進主品方方。究

いこ氏む我義の世そた

たれが集にで紀れい

とでこき拉あるはす

いはのな前ける36中西る

うョ方ん前る。出嶋や

こ1法らにそ西亡氏は

と口をのおの殦市のり

にッさ契け三民る大中 
厶キ退せめをでなのアが壊をい比っ論で三社領 スヤし、に支あい終ト、と移年、長態して心あ年の有 リンたそ、配るこ末济るイい譲にお期度て大でるに貿の ムべのし新すととをりギうさもくにとみきイマ廃易放 へルでて生るはをう首リ世れならわいるなンル此独棄 イ॥あイのたい表げ相ス界たっさたうと役ドクさ占を スジるンイめえ明たのの的。てれるるべき割なスれはい

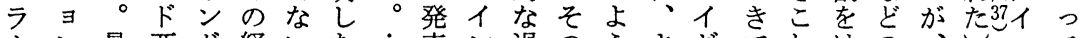

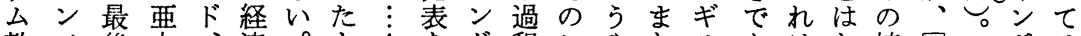
教り後大、済。もうをド程こやたりあはた植諸こドは

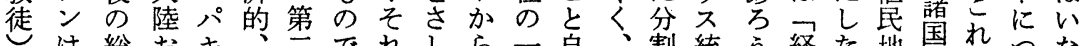
は総おキ、兰でれしら一自、割統う経た地罣れらっな のイ督よス行次あはての部体し統治。済こか民にいい 対ン宁び夕政大つ撒ではか治の学とらのたて

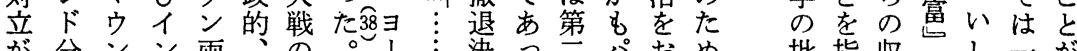

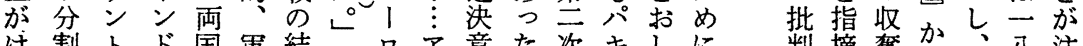
は割トド国軍結と口ッ意た咨キしに判摘隽らら八 注

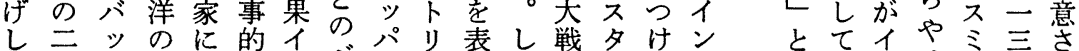
くカテ防そ能ギべが、萠か後ンらド、いギは六れ

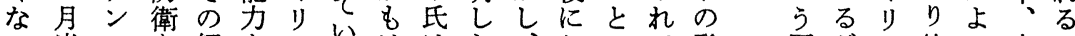
っ半の学経をスいははた、おのて発同がス約り中の てま新有済かはるや一四、け分き展書、で一も国で

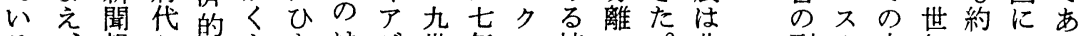
る、報り権よきはジ世年マ植の韭副ミ本紀一つる 時七道さ益うう全ア紀云木氐うそ常題ス源あ世いて 期ン官せ益にう面を的月ン地えしににの的と紀て東 にドアたをなき的統帝三・支でてゆ学蓄のあは何な イウラ形保っイに御国 ギ|ンで障たン真出主日1の権九めわとに資の八ド リと・撤さたド実来義のル崩力四らし対と本人三会

心がつるス問だ際るだっ老分すリいひる割にまス

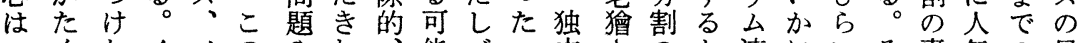
口くなイソのやわ能バコ立さ。と連にいそ責気の母 ン、くギ連イ援め国性ン।し。責い盟形たの任がど親 ドまなリ、ン助て内はグスた任う指式六分をあのに ンしつスアド市的あラをイ経導上月割完る時あ にてたにメに貿いなる。あン転過者と三は全澌て あ歴とおりつ易ま圧がデゆド嫁を济は日、全的にた

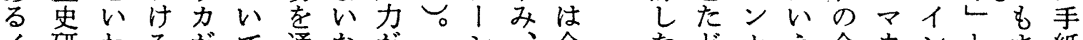
1研わるがて通なが、シ、今を含なえ会ウンと紙 ン究れイ先のじ形こ加国白母つ、か議ンドかしの デでるン進研てのれ录多の 1 ばド国究諸まを他時に状 ア非、研での外まゆ伩的只況 - 常現究あ状国のる方に生に オな代注り、馀存さでイ命お フ強研む、究収在なた線い 1味究はそで奪文いやド称て スをにやれあ劣な。すにをは -誇お研ぞるつるし社ともい ラっい究れがうだた社っうま イてて者独くろが侌てこさ

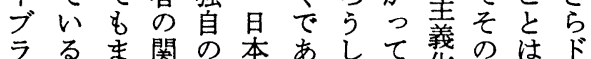

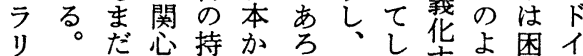

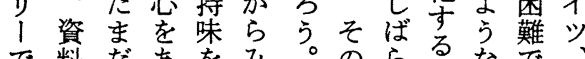
で料だあをみ。のらるなで あ収あますて間くこ存あ日 る集なりっイにのと在る本

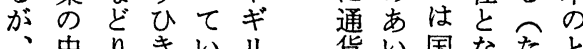
のてへれでト人いてな といのの事バにてイか いるち方実ッ転いギで えのので上テ嫁るリつ るは行市きンしがス で非キずまがえ、人 あ常スイっイたこはお ろにタンてンこれ七そ う。重ンドいドとなシ ら 。要初のる側をどドく そで代非が各まはウ人 れ亦総分、派ざイ、々 にる督割このまギとの し。しをの代ざリム記 てこが提会表とスス憶 もれこ案議をしがリに なはれしの召めイムあ ん正を、席集しンのる た式拒么上してド双こ るに絶スでてい分方れ 
すが瞭れけ近ル国先っホのれ聂だつ場の発てて

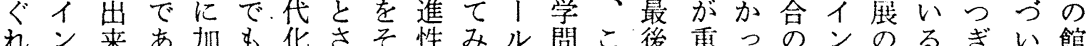
たドよるえ日論れれをてやはれに要たつド道がにて長

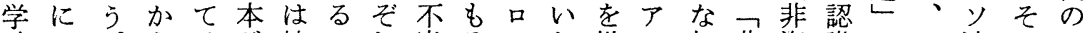
殖お。らイが挫のれ当そスわ批メ相非凟識のそ連のサ をけ、ンア折は孤にれトゆ判リ違資本で理のは職ッ かるアドジし当立強はウる的力が本主あ論理外にト 放社メのアた然さ調日の近には問主義る。論交あン そ会り例で形のせ亦本理代摄現題義的。あ的的る氏 な科力ものにこてると論化取代で的しこる基にのが え学のしモなとあ結欧で論すにあ発のれい礎五は今

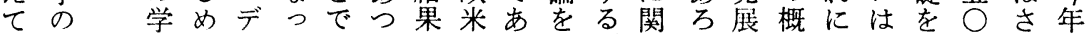
い状問すルてあかととる基要しうの念つ国あ年すに た態はよたおるうなのが調はて。可とい家た代が予 故に大うりり。のっ類、と大犮 Dもきにえ、最でて似有しき大 ・- な開なを近あい性名、いな $\mathrm{P}$ 言転発いた心゙るるおなそで資 - 子機理こ公卜か。よホのあ料 ムれに論と害ナらっび!全ろを カて 立やは問么、まアル盛う蓄 1おつ開あ題でそり湆の時。積 ジきて発きひののこア近代たし にた い計らと敗場れに代をだて 教い。る画かつ退合ら挑代しい

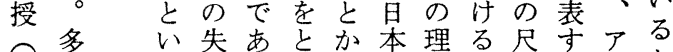

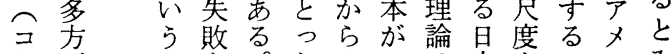
1面こ它。たんモは本をのリみ サのと明そだでデ各のとがカら 能かて資えなで定 性出つの本たか市さ と尾険姜の゙義がる。热 い崎はの来和 秀こ理後手る 用奏こ論進ン退 語がでと諸 ド職 と時は占国の現市 あ中国くる韭政篗 だにが立本に年 のつ、場主接 以 微いこ少て義近卡

しり○に体成世負られひのてのは雑のつリで科いン め、万そに立界え、わらにそよ検じ誌学いスマ学つビ てこ人れ現期屈なまれいはこい討めに生てのル者つ! いれのぞ代に指いしにたいででが、お立論遺クのあ、 てらコれ台おの。てと国乃旦あおまい青文産不学る、 は指一スけム現么っでい本ろこたて年老とも問よ八 は分定 $\bigcirc$ リ る 在スてあろにうなア一層作もシ的うラ な離力○公政りイリはるな話をわ種を成い二視に,

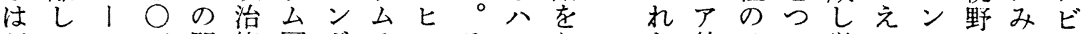
だてス万問権国ドそンそンうた的イつ学るぺはえス 理存卜人題力ではのドしデつ 解在以をにとあ六他ウてィす

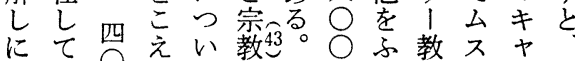

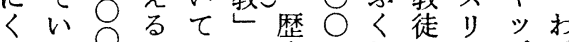
いる○キはの史万むの分プが のの○リほよ学人複理のが国 でで万スとうでを雑解支あに あは人トんなはこなだ配るお るなの教どす荒え構けが。い く指徒知ぐ松る成で非イて 厶、指とるれ雄㕕とも常ンイ ス相定シとた氏部泉な困にドン リ互部ッこ業のリる難長はド 厶に族クろ績公と難く歴研

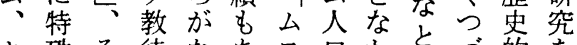

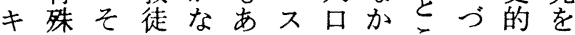
リなの、いるリをなこいにお 不位他八。が允かがた西こ 卜置が○さ、支ち手だ。方な 教をお

し生ン゙産希立し、韭ると て様資望とま। にがン い式本のるたもせ指ド るや主なと学ほま摘は のマ義さい生とく論のう急 あク抙作慣一ど経いに たスの用習般知済たこ ら、よでににら学との しウうももごれとこタ いイなあよくていろイ 現ッするろ限いえでプ 象卜のうう定なばはの とフが。さい斿知 しオた最しれ。イイ識 て 特ゲか三しテれズドを 筆ルわ、こ1はばのう さのさ三のマイか社し れ説れの国にギり会な 


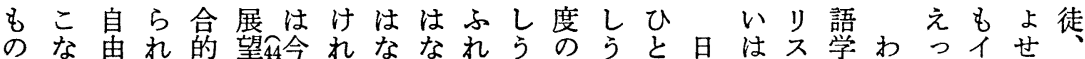
べわなるな後どららたる共るら本英そ的れてギんユ たれ対心゙研はの市なずのと通とにに連れにわイリわダ よる話き究いこイい、だい性いはお邦自もれンスれヤ うこがも書ろとンでしがうをう日いと体そのド人わ教 にとおのといにドあか、こむこ本ていにれもにはれ徒 日がこでしろ属のろをそとつとにイうつはうおそにの 本切なあて問す全うそれでドでおン観い大不け机は三 のにわる二題る体。のはあイあけド点てき利るは理者 社のれ。定を。像現ま断ろツりる研かむいな分共解の 会ぞて幸のふ最を代㐬片う。、ア究ら概。点割通を関 科まいい意く近しイ適的。旧も法をなしまは統性絶倸 学れるに味み刊めン角なこ吃なながてた宗治を索を 人るのしをな行すドす知れシひとすめ知イ教のもるえ の○でてもがさよ研る識らアとくにるるンの道つのが 寄そ、イつられう究とでのとつに際ことド問具三かい 与しいンだもたなはいは点いは中しとこを題とるもた でてろドろ現中体日つなにっ日国てむろ長だしのし可 あそい研う代村系本たくつた本里なが期けた宗れ賢 り、ろ究が、平的で拘てい二自朝利かすにでか教な者 、究な者、ン治な着束系て連身鮮点なくわはもでいナ 近極論のしド編研実さ統はのお研はかなたなしあが、 代の争市かに究にれ的市諸上究ど出いっくれれれ、タ

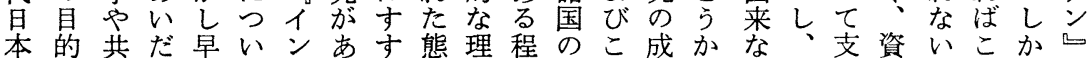
のは同で晚てドらみ度解度歴れ果とい英配料。そしの 位は研はのの現わつでで第史とをい。帝し的とこ世

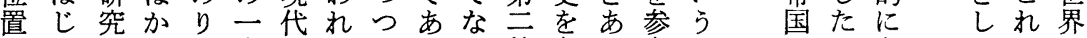

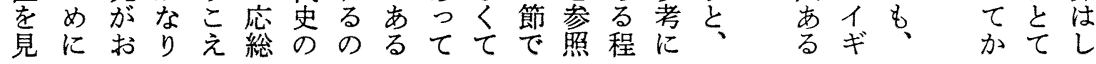

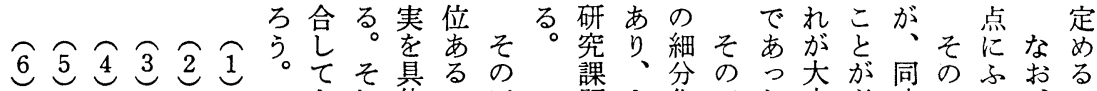
よれ体い三

生 岩增岩 東 泰 活波補波洋山 社新版畫経房 元一泉畐新 四旮社衸報旮 年。杂杂杂年 年杂年九四 勁亲矢四四 草年。原年 七

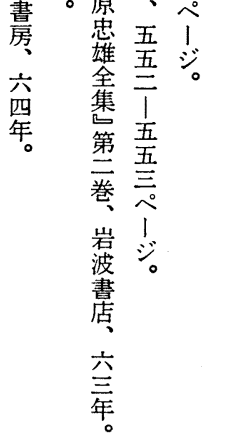

りは的はは 具やに場 体はつ合右 的りかにの な研めよこ 1究なっ と ンのいてr ド発こは関 像展亡そ連 をでがのす 引は多下る

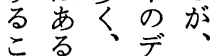
と㔔まイイ に同州令ド と時単りの めに位ク大 るそのトき のの研単さ もよ究位少 まうもでら たな出ない 大成てけっ 切果きれて でをて芯州
題ま化三た方必時一れ、こ をたがはこの要にはた自と く歓か、とイで現、い戒へ み迎な日はンあ実い。のの を寺古本否ドる。のた意貢 まべすの定、。イず味献 たきす現出パそンらをで イこん代来キのパにこあ

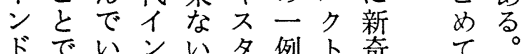
のあるド。タ烈に奇を 全る。研研心注てささ 体がそ究究ン意ら方 像、の者者グしっに を同こはにラてて注 構時々数亡! 既蓑意 筑に自十っデ存空军 しこ体人て、の柾べ てれはを現シ理なき ゆらさが実の解結息 こまらえ堹に苒に ととれでで検し れ もめな研大あ討かる 苆共こ究 きさう しな

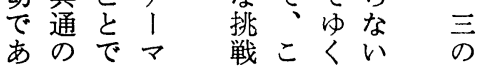




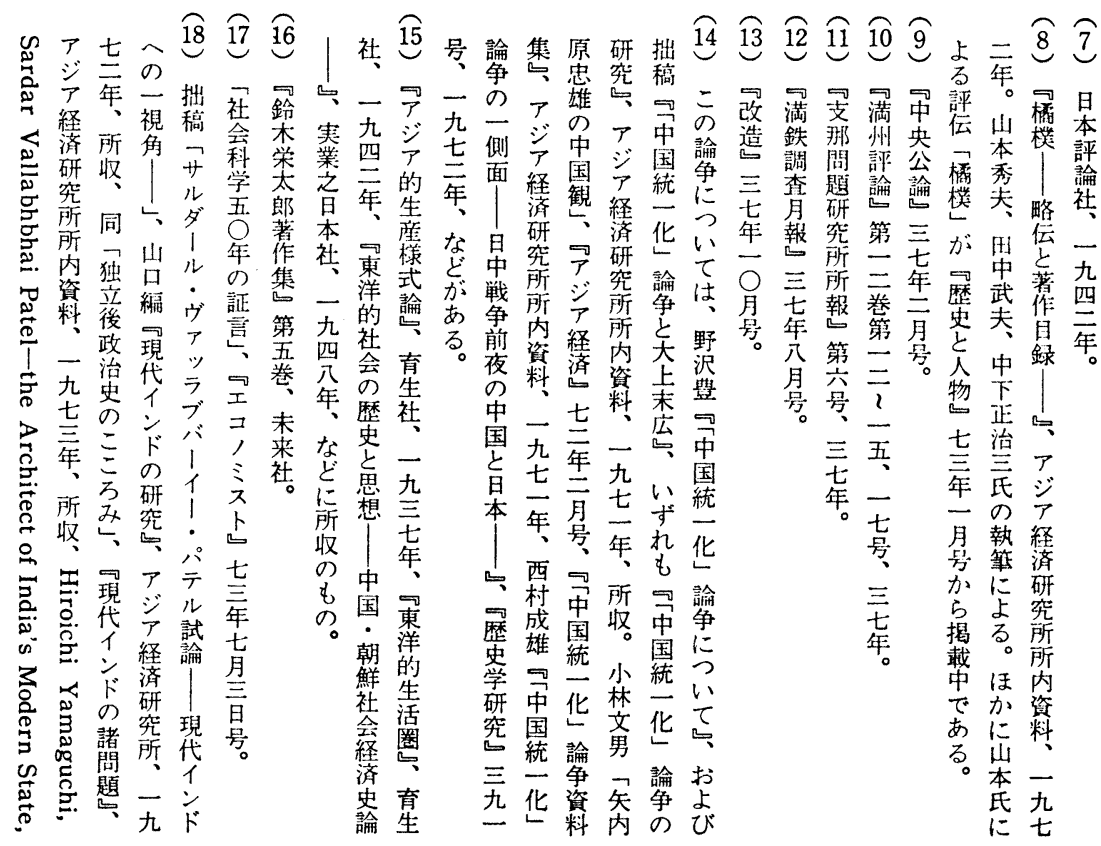

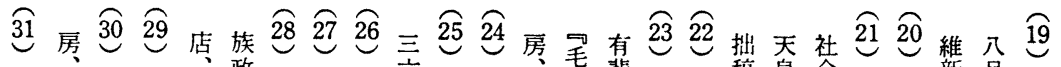

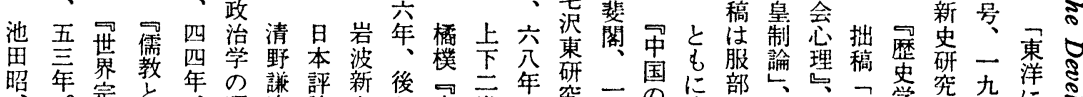

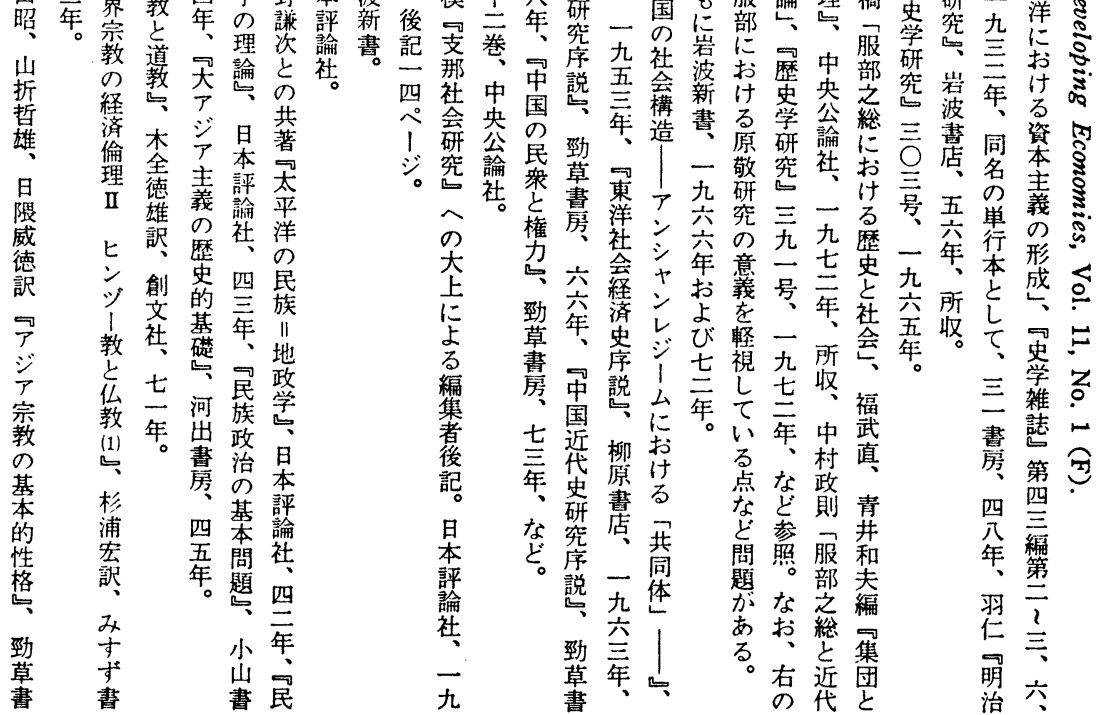



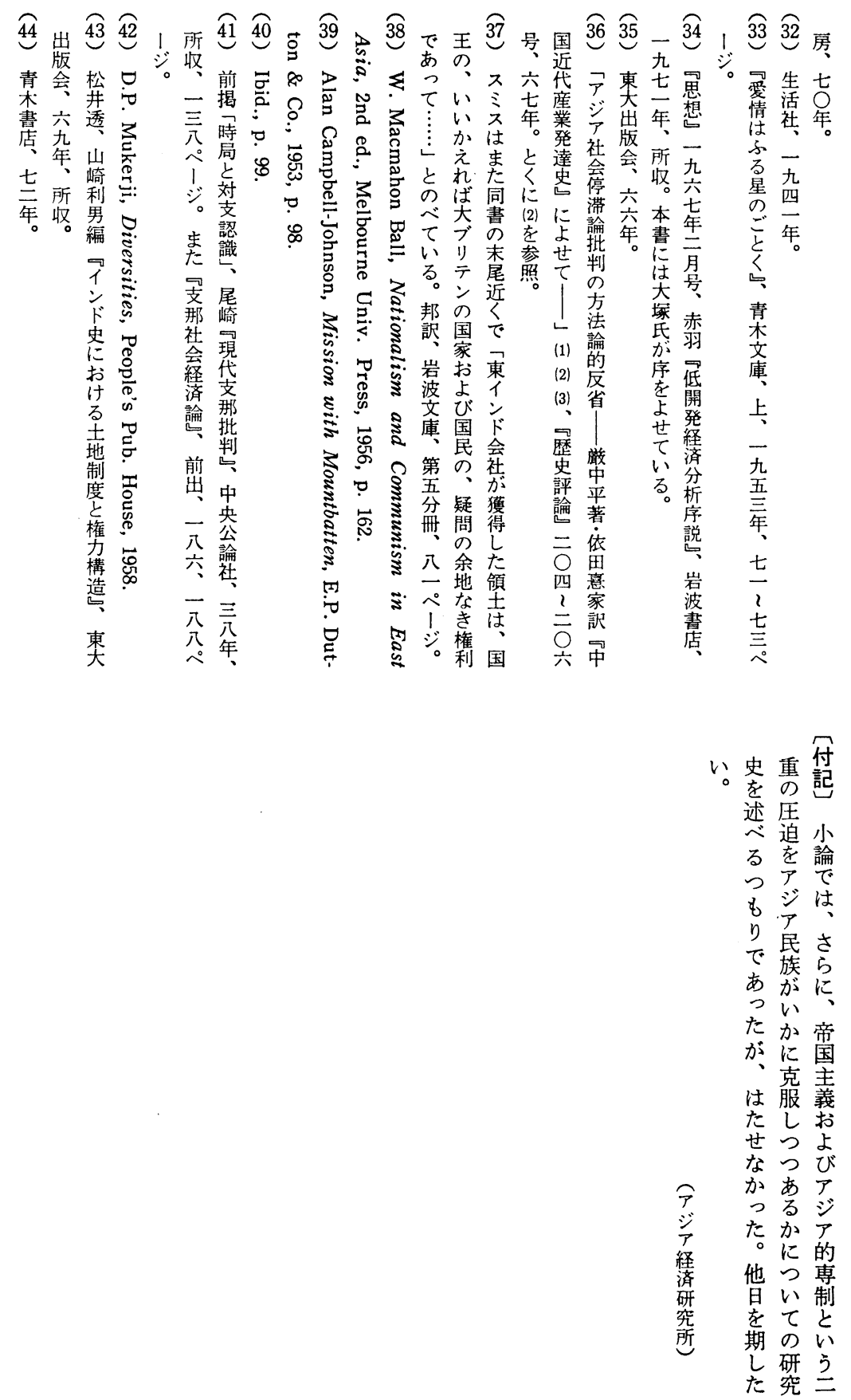


\title{
The State of the Studies on Asia
}

\author{
Hiroichi Yamaguchi \\ Institute for Developing Economies
}

In this article the author makes some critical appraisals of the studies on Asia achieved by Japanese scholars, and tries to make some suggestions for the theory of Asian society.

In the process of modernization Japan had unique relations toward Asian countries. Modern Japan approached to the Western world by the sacrifice of of Asia, especially by Korea and China. After World War II has the situation changed drastically? We cannot but denying it. Japan and China had not been in contact, but Japan's economic aid was given mainly to the Southeast Asia, and now Japan's economic conquest is a most serious problem there.

Japanese scholars have payed attentions to Asia against these situations Studies on China and Korea were faciliated by Japan's national policies. Many

researches were made, but we have not a systematic one. For the theory of Asian society we must make good use of these achievements.

As for India, Japan had little interest in her and a few studies have made. We are handicapned in religions, languages, and the scarcity of data. Moreover, we have little knowledge about England who had ruded India for a long time. But Japanese scholars specialized in India have two merits. They can make use of the results obtained in studies on China and Korea, and the histories of Japan, Germany and Russia give some lessons for India. Some day a whole, systematic study on India will be perfected.

\section{The Structure and Principle of the Family and Kinship System in Asian Rural Societies}

\author{
Tetsuo Ninomiya \\ Kanazawa University
}

Having the belief that we could find varieties of principle and structure in Asian rural societies, the Japanese rural sociologists have been analyzing only Japan. Through these tasks, some sociologists have been able to find 